\title{
Terra Academica
}

\author{
Іван Альмес
}

\section{Lectio Orthodoxorum: Книжкові зібрання православних монастирів Львівської єпархії наприкінці XVI - у XVII столітті*}

Здійснено спробу з'ясувати «читацький канон» та охарактеризувати книжкову культуру православних монастирів ранньомодерного часу київської традиції на прикладі чотирьох обителей Львівської єпархії - Крехівської, Львівської Святоонуфріївської, Підгорецької та Теребовельської. Вибір цих монастирів зумовлено станом джерельної бази, а основними джерелами слугували «списки книг», що їх зазвичай подавали в інвентарних описах. Усі досліджені книжкові зібрання були невеликими за обсягом порівняно з тогочасними католицькими кляшторами, зокрема, найбільше 3-поміж відомих, крехівське, налічувало лише бл. 100 томів. Lectio Orthodoxorum монахів Львівської єпархії XVII ст. - це, окрім богослужбових книг, своєрідна «тріада»: святоотцівська духовно-аскетична спадщина, житійна (агіографічна) та проповідницька література. Практично немає античної спадщини - творів давньогрецьких та давньоримських авторів, на вивченні яких базувалась гуманістична система освіти, у тому числі в церковних релігійних закладах. Це опосередковано говорить або про освітній рівень ченців, або, можливо, про відсутність «практичної» потреби у такій лектурі - на відміну від обителей, при яких діяли навчальні осередки. Чи це може бути одним зі свідчень того, що для насельників досліджуваних монастирів основним залишалось молитовне життя, а не «інтелектуальна» праця? Чи такий склад і невеликі обсяги книжкових зібрань можуть виступати одним із аргументів для розгляду

* Статтю написано за підтримки стипендії Міжнародної програми для докторантів Європейського університету Віадріна (Франкфурт на Одері, Німеччина): Fellowship by Viadrina International Program — for Graduates 2017, Viadrina European University, Frankfurt (Oder), Germany. Дякую анонімному рецензентові за слушні зауваження та уточнення. 
цих монастирів як місць, де панував lex orandi, натомість інтелектуальна діяльність, зокрема ангажованість у читання, не видавалася необхідною? Відповідь на ці питання вимагає подальших досліджень.

Ключові слова: монастирська бібліотека, книжкова культура, монастицизм, «списки книг», Slavia Orthodoxa, Львівська єпархія, Крехівський монастир, Львівський монастир Св. Онуфрія, Підгорецький монастир.

Ранньомодерну добу інколи називають «епохою монастицизму» як на західноєвропейських і річпосполитських, так і українських теренах з огляду на активізацію чернечого життя, що проявило себе, серед іншого, у зростанні кількості монастирів між XVI - серединою XVIII ст. ${ }^{1}$ Повноцінне богослужбове життя обителі, функціонування навчальних студій, місійну та катехитичну діяльність, зрештою духовно-інтелектуальну формацію ченців уможливлювали зібрання книг, що постають як невід’ємна складова монастирів. Звісно, не кожна обитель мала власну бібліотеку, та й у невеликих монаших осередках («скитиках») навряд чи існувала така потреба, але зазвичай навіть тут не обходилися без богослужбових книг, потрібних для молитовного життя. Це означає, що книги за означенням були в усіх монастирях, але не скрізь існували бібліотеки як такі. Метою цієї статті $є$ на прикладі чотирьох монастирських книгозбірень охарактеризувати книжкову культуру православного монашества київської традиції на теренах Речі Посполитої та, зокрема, змоделювати певний «читацький канон», притаманний насельникам православних обителей Львівської єпархії XVII ст.

${ }^{1}$ У католицькій традиції «монастицизм» буквально означає «чернече життя», у вужчому розумінні - монастирі «старого типу», що провадять життя за правилами Бенедикта Нурсійського та Августина Аврелія: Marek Derwich, «Monastycyzm w Polsce średniowiecznej i nowożytnej. Uwagi terminologiczne», in Christianitas et cultura Europeae. Ksiegga Jubileuszowa profesora Jerzego Kłoczowskiego (Lublin, 1998), 1: 256. Детальніше див.: G. R. Evans, The History of Monasticism. The Western Tradition (London; New York, 2016). Термін «монастицизм» застосовують і щодо чернечих осередків східнохристиянського обряду, пор., наприклад, статті «Eastern Christian Monasticism» чи «Orthodox Monasticism» в енциклопедіï: Encyclopedia of Monasticism (Chicago; London, 2000), 2: 976-983). За підрахунками дослідників, чернецтво (найчисельніше серед духовенства) як соціальний стан залишалось вагомою часткою населення Європи до середини XVIII ст., приміром, в Іспанії це співвідношення сягало 1:100: Derek Beales, Prosperity and Plunder. European Catholic Monasteries in the Age of Revolution, 1650-1815 (Cambridge, 2003), 2-4. 
Вибір для аналізу чотирьох монастирів зумовлено станом джерел, а саме: збереженістю «списків книг», які зазвичай наводили в інвентарних описах. Такі списки відомі для Крехівського і Теребовельського Преображенських та Львівського і Підгорецького Святоонуфріївських монастирів. Хоч подібні переліки укладали й у решті обителей (наприклад, є згадка про реєстр книг Унівського монастиря ${ }^{2}$, проте на сьогодні виявити їх не вдалося. Попри вузькість проналізованої вибірки вона, гадаю, все ж дозволяє змоделювати певний «читацький канон» чи, принаймні, з’ясувати потенційне «коло читання» тогочасних ченців - т.зв. lectio orthodoxorum.

У Львівській єпархії упродовж 1596-1739 рр. зафіксовано існування 88 чернечих осередків - без врахування поодиноких згадок про монастирі тільки за назвами ${ }^{3}$ У Уім, лише кілька десятків 3-поміж них функціонували стабільно та були більш-менш забезпеченими: станом на 1640 р. серед таких нараховують 18 «більших» та 21 «менших», де жило до шести насельників. Найбільшими обителями були Скит Манявський та Крехівський монастир: тут у різні періоди другої половини XVII ст. мешкало, відповідно, понад 100 та бл. 40 ченців ${ }^{4}$. Идеться про обителі з аскетичними практиками і строгістю чернечого життя за візантійським ${ }^{5}$ чи афонським взірцем, про що

2 Пор. згадку в одному з документів Унівського монастиря про те, що цій обителі заповіли два Євангелія та «инъшие книги грецкие, словенъские, и латинъские, и польские, коштовъные, оправные, которых ест особъный реестр»: «Запись отца Даниила Половковича от имени Өеодосия Сосновского, архимандрита Уневского и Четвертинского», в Архив Юго-Западной России, издаваемый Комисиею для разбора древних актов при киевском, подольском и вольнском генерал-губернаторе [далі - Архив ЮЗР], (Киев, 1904), ч. 1, т. 10: 521 .

${ }^{3}$ Andrij Pawłyszyn, Monastery męskie eparchii lwowskiej w latach 1596-1739. Praca doktorska (Lublin, 2006), 18-30, 176-264 (рук.). Дослідники здійснювали спроби каталогізації монастирів Львівської єпархії ранньомодерного часу ще з другої половини XIX ст., детальніше див.: Andrij Pawłyszyn, «Prawosławne i unickie monastery męskie na terenie eparchii lwowskiej w latach 1596-1739. Przyczynek do powstania nowego katalogu», w Klasztory mnisze na wshodnich terenach dawnej Rzeczypospolitej od XVI do początku XX wieku, red. J. Gwiożdzik, R. Witkowski, A. Wyrwa (Poznań, 2014), 277-286.

${ }^{4}$ Pawłyszyn, Monastery męskie eparchii lwowskiej, 152-156.

${ }^{5}$ Інокентій Гізель у «Мирі з Богом чоловіку» пише про ченців у категоріях «класичної» східної монашої традиції, на відміну від церковних єрархів та 
свідчать устави Крехівського ${ }^{6}$ та Манявського монастирів ${ }^{7}$. Обитель Св. Онуфрія у Львові функціонувала під патронатом Львівського $\mathrm{У}_{\text {спенського братства }}{ }^{8}$ як невеликий чернечий осередок, де в $1662 \mathrm{p}$. мешкало лише четверо монахів 9 . Значно більшою була обитель у Крехові: іï заснували на початку XVII ст. ченці Йоіл та Сильвестр, a 1628 р. Константинопольський патріарх Кирило Лукаріс надав монастирю статус ставропігїі10. Якщо в перші десятиліття його існування тут налічувалось близько 12 насельників ${ }^{11}$, то на середину XVII ст. їх було вже кількадесят ${ }^{12}$.

У Підгорецькій обителі чернече життя активізувалося у 16591665 рр., після приходу сюди зі Скиту Манявського монахів Созонта Ломиковського та Іллі Гостиславського. Згідно з грамотою від 10 грудня 1663 р. луцького й острозького єпископа Гедеона Святополка-Четвертинського, тут мали наслідувати монастирський чин

«білого духовенства», для кого він акцентує увагу на освіченості: Інокентій Гізель. Вибрані твори у 3 томах (Київ; Львів, 2012), кн. 1, т. 1: 305; Лариса Довга, Система иінностей в українській культурі XVII століття (на прикладі теоретичної спадщзни Інокентія Гізеля) (Київ; Львів, 2012), 167-168, 173-174.

${ }^{6}$ «Духовный завъть ієросхимонаха Іоила игумена и основателя Креховского монастыря 1638 года», в Науковый сборник, издаваемый литературным обществом Галиико-Русской Матицы. Год изданія четвертый 1868 (Львов, 1869), I-IV: 321-334.

${ }^{7}$ «Завіт духовний ієросхимонаха Феодосія, колишнього ігумена святої обителі Скитської, для розуміння і виконання духовному настоятелю ігумену, який після мене буде, і всім у Христі отцям і братам моїм та дітям по духу, яких зібрала благодать Божа», в Великий Скит у Kapnamax, т. 1: Патерик Скитський. Синодик, гол. ред. М. В. Кугутяк (Івано-Франківськ: Манускрипт-Львів, 2013), 252-275.

${ }^{8}$ До 1589 р. монастир перебував під духовною опікою ігумена Унівської обителі: Володимир Вуйцик, «Монастир Святого Онуфрія у Львові», в Вуйцик В. Вибрані прачі. До 70-річчя від дня народження (Львів, 2004), 49.

${ }^{9}$ Pawłyszyn, Monastery męskie eparchii lwowskiej, 218-220.

${ }^{10}$ Петро Шкраб 'юк, Крехів: дороги земні і небесні (Львів, 2002), 15, 27-29, 41, 44.

${ }^{11}$ «Духовный завъть ієросхимонаха Іоила», 322-323.

${ }^{12}$ Ігор Мицько, «Ідеологічна боротьба на Україні в XVII ст. і формування та склад бібліотек», в Бібліограбічна інформація і сучасність: збірник наукових працьь (Київ, 1981), 103. 
Великого Скита, тобто Манявської обителі ${ }^{13}$. Подальшого розквіту монастир набув за ігуменства о. Парфенія Ломиковського (16871729), коли було зведено новий монастирський комплекс, написано знаний Синопсис Підгорецького монастиря, тощо ${ }^{14}$. Ігумен звертав увагу і на формування монастирської бібліотеки, зокрема особисто зібрані книги він заповів обителі ${ }^{15}$.

До числа «середніх» монаших осередків Львівської єпархії належав Теребовельський Святопреображенський монастир. Достеменно невідомо, відколи існувала ця обитель - вірогідно з XVI ст. ${ }^{16}$ У 1663 р. тут сталося чудо - заплакав образ Божої Матері, який дев'ятьма роками пізніше «unikaiąc inkursyi tatarskiey...» за розпорядження владики Йосифа Шумлянського, перенесли до собору св. Юрія у Львові «у tymże zakonnikom w dozor y piłność oddany» ${ }^{17}$.

Основним джерелом для реконструкції кількісного та змістового складу книгозбірень досліджуваних монастирів слугують «списки книг» в інвентарних описах. За даними Уршулі Пашкевич, для теренів Галичини XVII ст. збереглося лише три таких описи книг: Крехівського (1637 р.), Домашівського (1668 р.) та Підгорецького (1699р.) монастирів ${ }^{18}$. Дослідниця не згадує переліку книг Теребовельської обителі 1676 р., який буде використано у цій статті (для порівняння, книжкові каталоги монастирів Києва відомі з XVIII ст. $\left.{ }^{19}\right)$.

${ }^{13}$ Великий Скит у Kарпатах, т. 2: Великий Скит у документах і матеріалах XVII-XXI ст., за ред. М. Кугутяка (Івано-Франківськ; Манускрипт-Львів, 2015), 60-61.

${ }^{14}$ Іван Йосафат Скрутень, ““Синопсис” Пліснесько-Підгорецького монастиря», Записки ЧСВВ т. 1, вип. 1 (Львів, 1924): 92-103; т. 1, вип. 2 (Львів, 1925): 303-313; т. 1, вип. 4 (Львів, 1927): 580-591; т. 3, вип. 1 (Львів, 1930): 156-164.

${ }^{15}$ Марія Кольбух, «Книгозбірня Підгорецького монастиря: історія формування», Записки Львівської національної наукової бібліотеки України імені В. Стефаника: зб. наук. пр. 3 (19) (2011): 395.

${ }^{16}$ Володимир Вуйцик, «Оборонний василіанський монастир в Теребовлі», Вісник інституту «Укрзахідпроектреставрація» 11 (2000): 39, 43.

${ }^{17}$ Національний музей у Львові імені Андрея Шептицького [далі - НМЛ], Відділ рукописної та стародрукованої книги, Ркл-141, с. 205-206.

${ }^{18}$ Urszula Paszkiewicz, Cathalogus cathalogorum. Inwentarze i katalogi bibliotek $z$ ziem wschodnich Rzeczypospolitej od XVI wieku do 1939 roku (Warszawa, 2015), t. 1-2.

19 Див., наприклад, згадки про описи бібліотек Золотоверхого Михайлівського (1769 р.) та Пустинно-Миколаївського монастирів (1787 р.): у 
Найдавніший із відомих інвентарних описів книжкових зібрань монастирів Львівської єпархії міститься в інвентарі 1579 р. обителі Св. Онуфрія у Львові (його опублікував Василь Кметь ${ }^{20}$ ). У цьому документі подано скорочені назви книжкових позицій, а про «позабогослужбові» книги записано «ещє єі [15] книг розмаитых стародавных» ${ }^{21}$. Для реконструкції Крехівської книгозбірні першої половини XVII ст. джерелом слугує інвентар 1637 р., проте відмінність почерку записів на початку та наприкінці списку книг дозволяє датувати його кінцеву частину пізніше 1637 p. ${ }^{22}$ Опис книг Теребовельського монастиря походить з інвентаря 1676 р. (у цій статті використано його копію $\left.{ }^{23}\right)$. Врешті, у 1699 р., за ігуменства Парфенія Ломиковського, було складено (скоріш за все ним) інвентар Підгорецького монастиря, найраніший із відомих для обителі. Особливістю цього джерела є вказівки при кожній із позицій про належність книги або монастиреві, або о. Парфенію ${ }^{24}$.

У всіх щойно зазначених описах подано назву або ім'я автора книги (зазвичай у скороченій формі), інколи вказано, чи йдеться про рукопис, чи про друк. Місце видання, друкарню та рік публікації у списках не наводили, відтак, з інвентарного опису достовірно можна дізнатися лише про загальну кількість книг та про те, чи

першому було близько тисячі книг, у другому — понад 800. Див.: Олена Дзюба, Віра Фрис, «Бібліотеки України», в Історія української культури у 5 томах, т. 3: Українська культура другої половини XVII - XVIII ст. (Київ, 2003), 816-818. Див. також: Максим Яременко, «Київські монастирські та приватні чернечі бібліотеки XVIII століття і «літературні уподобання» монашества», Український археографічний щзорічник 8/9 (2004): 346-365; Оксана Кошіль, Василь Ульяновський, Старожитня бібліотека Михайлівського Золотоверхого монастиря: спроба реконструкиї кириличної збірки (Київ, 2008).

${ }^{20}$ Василь Кметь, «Інвентарі Успенської та Святоонуфріївської монастирської церкви у Львові 1579 р.», Вісник Львівського національного університету. Серія історична 35 (2000): 494-510.

${ }^{21}$ ЦДІА України у Львові, ф. 129, оп. 1, спр. 1033, арк. 3.

22 Детальніше про інвентарні описи книгозбірні Крехівської обителі див.: Iwan Almes, «Źródła do historii bibliotek klasztornych eparchii lwowskiej XVII-XVIII wieku. Inwentarze bazyliańskiego monasteru w Krechowie», Textus et studia 3 (2015): 7-27.

${ }^{23}$ ЦДІА України у Львові, ф. 684, оп. 1, спр. 3009, арк. 2.

24 Львівська національна наукова бібліотека України ім. В. Стефаника НАН України, відділ рукописів [далі - ЛННБ, відділ рукописів], ф. 3, од. зб. 76, арк. 67-70. 
йдеться про церковні і бібліотечні книги, та чи була вона друкованою або писаною. Варто зазначити, що на основі інвентарних даних неможливо дізнатись про конволюти, тобто книги, оправлені разом по дві й більше, тому існує ймовірність неточності кількісних показників.

\section{«За отпущеніе грьховъ»: з історії формування книжкових зібрань}

Незважаючи на часте дарування книг духовними та світськими особами з-поза монастирського середовища, основними «фондоутворювачами» книжкових зібрань виступали самі ченці. Про це свідчать записи іноків на книжках, що вони їх залишали/дарували обителі, а також опосередковані вказівки - наприклад, рукописні екслібриси. У XVII ст. своєрідним «книжковим ктитором» для обителей Львівської єпархії виступало Львівське Успенське братство. Зазвичай Ставропігія дарувала видання своєї друкарні Львівському Святоонуфріївському монастирю, оскільки братчики були патронами цієї обителі. Окрім того, братство часто обдаровувало книгами й чернечу братію Крехова (приміром, саме так у 1687 р. сюди потрапив Октоїх «za prosbą oyców krechowskich» ${ }^{25}$ ).

Дарувальниками книг виступали також церковні єрархи. Скажімо, коли 1633 р. у Львові відбулося поставлення Петра Могили в сан київського митрополита, то владика, перебуваючи в місті ще упродовж двох місяців, відвідав Крехівський монастир, де освятив Преображенський храм ${ }^{26}$ та, вірогідно, тоді ж подарував йому київське видання 1628 р. «Поученій» авви Дорофея ${ }^{27}$. Відомі й випадки авторських дарувань цьому ж монастиреві. Так, на примірнику київського видання 1669 р. книги «Месія правдивий» Йоаникія Галятовського міститься його автограф: «Ја по[д]лы[й] avторь сєи книги дале[м] сію книгу монастироvи Креховскому,

${ }^{25}$ Юлия Шустова, Документы Львовского Успенского Ставропигийского братства (1586-1788): Источниковедческое исследование (Москва, 2009), 622.

${ }^{26}$ Петро Шкраб 'юк, Крехів: дороги земні і небесні (Львів, 2002), 38.

27 ЛННБ, відділ рідкісної книги, ІІ ст. 2348, арк. 2-9 зв. 
ж[е]бы та[м] за мєнє Б[о]гу прошень» ${ }^{28} .3$ бібліотечного зібрання львівського єпископа Афанасія Желіборського до крехівської книгозбірні перейшла Тріодь Цвітна, про що свідчить рукописний екслібрис ${ }^{29}$.

Восени 1648 р., під час облоги Львова військами Богдана Хмельницького, духівник гетьмана о. Йоан Гоголівський віддячив за подаровані йому братчиками шість богослужбових книг, надавши Псалтир Успенському соборові братства та Октоїх монастиреві Св. Онуфрія ${ }^{30}$. Дарування книг уважали також одним із виявів побожності віряни, насамперед знатні та заможні шляхтичі й міщани. Так, у 1610 р. Миколай Вистемик з Молдови подарував львівській обителі Св. Онуфрія коштовно оздоблене Євангеліє віленського друку ${ }^{31}$, а примірник видання «Nowa miara starey wiary» Лазаря Барановича потрапив до крехівської книгозбірні від котрогось із львівських міщан Красовських, які особливо опікувалися цією обителлю ${ }^{32}$. Зрештою, книги, переважно богослужбові, дарували й «звичайні» миряни: скажімо, у 1589 р. Євангеліє «купили праvослаvнии хри[с] тиане и придали» до Підгорецького монастиря ${ }^{33}$.

Меншою мірою книгозбірні формувалися шляхом купівлі книг, часто через Львівське братство, адже братчики не лише безкоштовно поширювали книги, а й продавали продукцію своєї друкарні

${ }^{28}$ Там само, II ст. 2361, арк. 2-3. Наталя Яковенко описує перебування Йоаникія Галятовського впродовж 1664-1667 рр. в Унівському, Скиті Манявському та Львівському Святоонуфріївському монастирях. Дарування книги Крехівській обителі із власноручним записом свідчить, що він, імовірно, відвідав і Крехівський монастир. Див.: Наталя Яковенко, У пошуках Нового неба: Життя і тексти Йоаникія Галятовського (Київ: Лаурус; Критика, 2017), 40-43.

${ }^{29}$ «Ex ca[ta]logo librorum A[ta]nazy Żeliborsky, episcopi Leopoliensis»: Каталог кириличних стародруків Львівської наукової бібліотеки ім. В. Стефаника НАН України, вип. 3: Видання друкарень Львова: Михайла Сльозки, Арсенія Желиборського, Йосифа Шумлянського, монастиря св. Юра (Львів, 2000), 30-31.

30 Ярослав Ісаєвич, «Зв’язки братств із запорізьким козацтвом у XVII ст.», в Ісаєвич Я. Украӥна давня і нова. Народ, релігія, культура (Львів, 1996), 109-110.

31 ЛННБ, відділ рукописів, ф. 3, од. зб. 132, арк. 10.

32 ЛННБ, відділ рідкісної книги, ст. II 30465.

${ }^{33}$ НМЛ, ркк-681, арк. 14-17. 
монастирям за зниженою ціною ${ }^{34}$. Утім, уривчатість згадок про купівлю книг у монастирській документації XVII ст. ${ }^{35}$ не дозволяє цілісно з'ясувати поширеність такої практики.

\section{Чисельність книгозбірень: церковні, рукописні та кириличні книги}

Кількісно монастирські книгозбірні в обителях Львівської єпарxiї XVII ст. були невеликими. У Львівському Святоонуфріївському монастирі за даними 1579 р. нараховувалось 53 томи у 43-х назвах ${ }^{36}$. Крехівській обителі в другій третині XVII ст., як уже згадувалося, належало бл. 100 томів $^{37}$, а в Підгорецькій обителі станом на 1699 p. було 76 томів у 68-ми назвах ${ }^{38}$. Серед менших чернечих осередків відомо про книзбірню монастиря у Теребовлі, де в 1676 р. зберігалося лише 33 книги ${ }^{39}$ (див.: Діаграма 1). Порівняти ці дані з обсягом книжкових зібрань тогочасних православних монастирів Києва чи Чернігова неможливо, бо їхні тогочасні описи не збереглися, проте можна припускати, що кількісні показники були приблизно такими самими. Що ж до Волині, то під 1614 р. у Почаївському монастирі

${ }^{34}$ Детальніше про дарування та продаж книг братчиками монастирям Львівської єпархії див.: Іван Альмес, «До історії формування книгозбірень монастирів Львівської єпархії в другій половині XVII - середині XVIII ст.», Історія релігій в Украйні: Науковий щзорічник 1 (2015): 83-98.

35 Пор. такі згадки: у січні 1663 р. ігумен Крехівської обителі Єзекиїл придбав на львівському ярмарку якусь книгу: «O[j]ciec igumen wydał we Lwowie na jarmarku za xięgą [...] 4 [zl.]» (ЛННБ, відділ рукописів, ф. 3, од. зб. 815, арк. 67 зв.); у 1689 р. Парфеній Ломиковський купив для Підгорецької обителі у львівського кравця рукописний список 1612-1613 р. Номоканону (Корогодина, Кормчая книга в Галиции, 152).

${ }^{36}$ ЦДІА України у Львові, ф. 129, оп. 1, спр. 1034, арк. 3 зв.; Кметь, «Інвентарі Успенської та Святоонуфріївської монастирської церкви», 494-510.

${ }^{37}$ ЦДІА України у Львові, ф. 129, оп. 1, спр. 539, арк. 3-4; детальніше див.: Іван Альмес, «До історії Крехівської монастирської бібліотеки першої половини XVII ст.», в Православ'я в Україні: Збірник матеріалів III Всеукраїнської наукової конферениї (Київ, 2013), 2: 386-397.

38 ЛННБ, відділ рукописів, ф. 3, од. зб. 76, арк. 67-70.

${ }^{39}$ ЦДІА України у Львові, ф. 684, оп. 1, спр. 3009, арк. 2-4. 
згадується лише 17 назв, і то переважно богослужбової літератури ${ }^{40}$. Більш-менш схожими були й показники кінця XVII ст. по унійних волинських монастирях Володимирської єпархії ${ }^{41}$. Співмірно виглядають і книжкові зібрання домініканських монастирів Волині: у Луцькому за даними 1609-1610 рр. було приблизно 70 книг, а у Володимирському на 1609-1613 pр. - 242. Як суттєво більші, натомість, постають тогочасні книжкові зібрання польських римо-католицьких монастирів (для прикладу, Краківському францисканському кляшторові вже наприкінці XVI ст. належало 718 кодексів ${ }^{43}$ ). Значно більшими були й книгозбірні російських монастирів. Так, у Троїце-Сергієвій лаврі станом на 1641 р. налічувалось 742 кодекси, а в

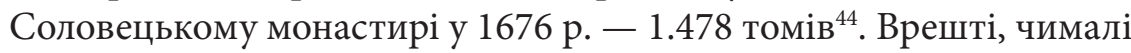
персональні зібрання книжок належали й тогочасним церковним єрархам, наприклад, митрополитові Петру Могилі ${ }^{45}$.

${ }^{40}$ Валентина Бочковська, «Історія Почаївського монастиря у візитаціях XVIII - першої чверті XIX ст.», Рукописна та книжкова спадщина України 13 (2009): 24-25.

${ }^{41}$ Наприклад, у Стоянівському та Низкиницькому монастирях зберігалось всього близько двох десятків книг (лише церковні), а в більшій Зимнівській обителі було майже 50 томів: Генеральні візитації церков і монастирів Володимирської унійної єпархії кіния XVII - початку XVIII століть: Книга протоколів та окремі описи, заг. ред. та істор. нарис А. Гіля, І. Скочиляса (Львів; Люблін, 2012), 19, 45, 49.

${ }^{42}$ Наталія Сінкевич, Laudare benedicere praedicare: Домініканський орден на Волині в кінці XVI - на початку XIX ст. (Київ, 2009), 163, 170.

${ }^{43}$ Hieronim Wyczawski, «Kościelne zbiory biblioteczne (wiek XVI-XVIII)», w Dzieje teologii katolickiej w Polsce, t. 2: Od odrodzenia do oświecenia, cz. 1: Teologia humanistyczna (Lublin, 1975), 533.

${ }^{44}$ Сергей Луппов, Книга в России в XVII веке, (Ленинград, 1970), 156; Маргарита Кукушкина, Монастырские библиотеки Русского Севера. Очерки по истории книжной культуры XVI - XVII веков (Ленинград, 1977), 127-139.

${ }^{45}$ За підрахунками Людмили Шаріпової, на середину 1640-х рр. книгозбірня Петра Могили могла налічувати понад 2 тис. томів, хоч ця цифра видається завищеною: Liudmyla Charipova, Latin books and the Eastern Orthodox Clerical Elite in Kiev, 1632-1780 (Manchester and New York: Manchester University Press, 2006), 83. 
Діаграма 1.

Чисельність монастирських книгозбірень

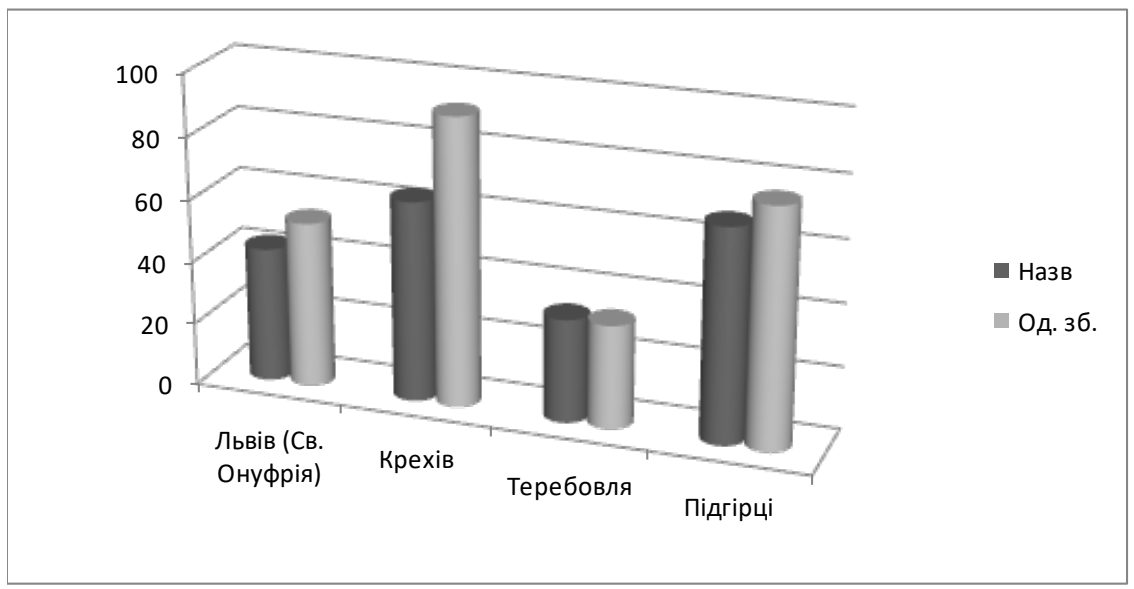

Джерела: ЦДІА України у Львові, ф. 129, оп. 1, спр. 539, арк. 3-4; спр. 1033, арк. 3; ф. 684, оп. 1, спр. 3009, арк. 2-4; ЛННБ, ф. 3, спр. 76, арк. 67-70.

Зазвичай в інвентарях книги описано за двома рубриками «церковні» та «бібліотечні». Під «церковними» мали на увазі ті, що зберігалися у монастирських храмах, і йдеться зазвичай про богослужбові книги, а під «бібліотечними» - всі, сказати би, «не церковні», що становили «бібліотеку» як таку. Щоправда, у досліджуваних документах такого поділу ще немає, бо монастирські книгозбірні були практично повністю «церковними» за складом. Це й не дивно, адже така література слугувала щоденним потребам, а фінансові можливості обителей та читацькі запити не передбачали закупівлі книг богословського, а тим більше «світського» характеру. У кількісному вимірі «церковні» книги охоплювали від 50 до 70 \% книжкового складу Львівського Святоонуфріївського ${ }^{46}$, Теребовельського $^{47}$ та Підгорецького монастирів ${ }^{48}$. Лише в Крехівській обителі вже у XVII ст. більшість книжкового фонду складали власне «бібліотечні» книги ${ }^{49}$, хоч їх і не було виокремлено в інвентарі спеціальною рубрикою.

\footnotetext{
${ }^{46}$ ЦДІА України у Львові, ф. 129, оп. 1, спр. 1033, арк. 3.

47 Там само, ф. 684, оп. 1, спр. 3009, арк. 2-4.

48 ЛННБ, відділ рукописів, ф. 3, од. зб. 76, арк. 67-70.

${ }^{49}$ ЦДІА України у Львові, ф. 129, оп. 1, спр. 539, арк. 3-4.
} 
Окремим питанням, яке можна вивчати на підставі інвентарних описів, $є$ співвідношення стародрукованої та рукописної книжкової продукції ${ }^{0}$. На жаль, суттєвим обмеженням для такого аналізу $€$ гіпотетичність висновків, адже більшість інвентарів не фіксує фізичних параметрів книги. Радше як виняток виступають описи книгозбірень Крехівського і Підгорецького монастирів, де вже в другій половині XVII ст. переважали друковані видання, що становили, відповідно, бл. 40 \% і 70 \% всього складу книг. У Підгорецькій обителі - це, зокрема, 52 томи із $76^{51}$, а в Крехівському монастирі 35 томів (ще 29 невідомо) із $92^{52}$.

Перефразований вислів Сильвестра Косова про церковнослов'янську ad chorum, а латину ad forum добре відображає призначення та побутування різних мов у чернечих середовищах київської традиції ранньомодерного часу ${ }^{53}$. Відтак, одним із важливих аспектів, який можна частково реконструювати на основі інвентарних описів, є мовний склад тогочасних монастирських книжкових зібрань. Проте, на жаль, і тут джерела не дають задовільної відповіді, адже в деяких інвентарях перелік книг подано лище однією мовою - або руською, або польською, хоч подеколи трапляється й «мовна» позначка при назві: "polska», «ruska», «latina». Узагальнюючи, можна сказати, що в XVII ст. у монастирських книгозбірнях практично повністю домінували друковані та рукописні кириличні книги, натомість польськомовну продукцію було представлено поодинокими працями (один том у Теребовлі ${ }^{54}$, два в Крехові ${ }^{55}$, шість у Підгірцях $\left.{ }^{56}\right)$. Логічно припустити, що в решті православних монастирів Львівської єпархії теж переважали

${ }^{50}$ Ідеться про рукописи монастирського архіву. Як слушно зауважив Казімєж Пекарський, «nie każdy rękopis, ani każdy druk jest książką». Цит. за: Maria Pidłypczak-Majerowicz, «Polska literatura bibliologiczna na temat badań proweniencyjnych w zbiorach starych druków. Zarys problemu», w Kraków-Lwów: Biblioteki XIX-XX wieku (Kraków, 2014), XIII: 7.

51 ЛННБ, відділ рукописів, ф. 3, од. зб. 76, арк. 67-70.

${ }^{52}$ ЦДІА України у Львові, ф. 129, оп. 1, спр. 539, арк. 3-4.

${ }^{53}$ Сильвестр Косов писав у трактаті «Екзегезис» (Київ, 1635) про грецьку ad chorum і латинську ad forum, в Архив ЮЗР (Киев, 1914), ч. 1, т. 8: 444.

${ }^{54}$ ЦДІА України у Львові, ф. 684, оп. 1, спр. 3009, арк. 2-4.

55 Там само, ф. 129, оп. 1, спр. 539, арк. 3-4.

56 ЛННБ, відділ рукописів, ф. 3, од. зб. 76, арк. 67-70. 
кириличні тексти, тож не буде перебільшенням назвати тутешні книжкові зібрання «руськими бібліотеками».

Насамкінець заторкну питання про формат та місце видання книг. Це можна частково реконструювати на прикладі книгозбірні Крехівського монастиря. Хоч при жодній з інвентарних позицій формату не вказано, проте на основі книгознавчої реконструкції його вдається встановити для 29 книг із 92, тобто для майже третини зібрання, а саме: бл. 17 книг були у форматі in $2^{\circ}$ (в аркуш), $11-$ in $4^{\circ}$ (у піваркуша) та одне - in $8^{\circ}$ (у чверть аркуша). Місце видання того чи того стародрука інвентар не зазначає, проте для 32 із 35 томів воно надається на встановлення: 13 книг із друкарні Києво-Печерської лаври, 10 Львівського братства, 4 Острога, 3 Вільна, по одній із Крилоської друкарні та Кракова. Як бачимо, більше половини стародруків - це київська та львівська продукція ${ }^{57}$.

\section{Тематична «тріада» православних монастирів}

У ранньомодерний час обителі постають як одне з традиційних «місць знання» ${ }^{58}$, що його розуміли не лише в секулярному сенсі, але і як християнську категорію знання, яке сприяє спасінню, тим більш коли мова заходить про монастирські осередки ${ }^{59}$. Відповідно, читацькі практики постають як один із аспектів історії знання, а опосередкованим засобом вивчення цього явища $є$ тематичний аналіз книжкового складу тогочасних бібліотек.

Богослужбові книги. Література такого змісту охоплювала більшість друкованої продукції на українських теренах досліджуваного часу. За підрахунками Ярослава Ісаєвича, у першій половині XVII ст. такі книги становили 44 \% всіх видань обсягом понад 66 \%

${ }^{57}$ Іван Альмес, «До історії Крехівської монастирської бібліотеки першої половини XVII ст.», 386-397.

${ }^{58}$ Peter Burke, Społeczna historia wiedzy (Warszawa, 2016), 73.

${ }^{59}$ Gregory S. Brad, The Unintended Reformation. How a Religious Revolution Secularized Society (Cambridge; Massachusetts; London, 2012), 299, 311. В одній із середньовічних сентенцій мовиться: «Scientia donum Dei est ergo vendi non potest», цит. за: Paweł Rodak, Pismo, ksiażka, lektura. Rozmowy: Le Goff, Chartier, Hébrard, Fabre, Lejeune (Warszawa, 2009), 52. 
друкованих аркушів ${ }^{60}$. Навіть, на Заході ситуація була аналогічою аж до кінця XVII ст. ${ }^{61}$ Природно, що необхідний комплект богослужбових книг для забезпечення літургійного життя зберігався у всіх монастирях, хоч в описах їх фіксували не завжди. Так, в інвентарі Львівського монастиря не записано Євангелія і Служебника, у Львівському та Крехівському монастирях - Требників, у Підгірцях та Крехові - Часословів, проте малоймовірно, аби їх там не було. Натомість брак Ірмолоїв у Підгорецькій та Львівській, чи Акафістників в усіх обителях, окрім Теребовельської, мабуть, відповідав дійсності, бо таку книгу не вважали «обов'язковою» для проведення богослужінь. Поза тим, описи Євангелій зазвичай наводили в інших рубриках - серед церковного срібла чи речей у вівтарі. Зведену інформацію про наявність богослужбових книг у досліджуваних монастирях див. у таблиці 1.

Таблиия 1.

Богослужбові книги в монастирських книгозбірнях

\begin{tabular}{|c|c|c|c|c|}
\hline $\begin{array}{l}\text { Назва } \\
\text { книги }\end{array}$ & $\begin{array}{c}\text { Львівський } \\
\text { монастир } \\
\text { (опис } \\
1579 \text { р.) }\end{array}$ & $\begin{array}{c}\text { Крехівський } \\
\text { монастир } \\
\text { (опис другої } \\
\text { третини } \\
\text { XVII ст.) } \\
\end{array}$ & $\begin{array}{c}\text { Теребо- } \\
\text { вельський } \\
\text { монастир } \\
\text { (опис } \\
1674 \text { р.) } \\
\end{array}$ & $\begin{array}{c}\text { Підгорець- } \\
\text { кий монас- } \\
\text { тир } \\
\text { (опис } \\
1699 \text { р.) } \\
\end{array}$ \\
\hline Акафістник & - & - & 1 & - \\
\hline Апостол & $1(4)$ & 4 & - & 3 \\
\hline Євангеліє & - & 4 & 4 & 5 \\
\hline Ірмолой & - & 1 & 1 & - \\
\hline Мінея & 13 & 1 & 1 & $2(7)$ \\
\hline Октоїх & $1(3)$ & 3 & 1 & 2 \\
\hline Півустав & - & - & - & 2 \\
\hline Псалтир & $1(3)$ & 1 & 1 & $4(5)$ \\
\hline Служебник & - & 5 & 5 & 5 \\
\hline Требник & - & - & 3 & 4 \\
\hline
\end{tabular}

${ }^{60}$ Iaroslav Isaievych, Voluntary Brotherhood. Confraternities of Laymen in Early Modern Ukraine (Edmonton; Toronto, 2006), 233.

${ }^{61}$ Sheila Hingley, «Ecclesiastical Libraries: Libraries for the Higher Clergy», in The Cambridge History of Libraries in Britain and Ireland, ed. by E. Leedham-Green, T. Webber (Cambridge, 2006), 132. 


\begin{tabular}{|c|c|c|c|c|}
\hline Трефолой & - & 1 & 1 & 2 \\
\hline Тріодь Пісна & $1(2)$ & 2 & 1 & 2 \\
\hline $\begin{array}{c}\text { Тріодь } \\
\text { Цвітна }\end{array}$ & 1 & 1 & 1 & 2 \\
\hline Часослов & 1 & - & 1 & - \\
\hline Інше & $9(10)$ & 2 & - & 1 \\
\hline Разом & $28(37)$ & 25 & 21 & $34(40)$ \\
\hline
\end{tabular}

Джерела: ЦДІА України у Львові, ф. 129, оп. 1, спр. 539, арк. 3-4; спр. 1033, арк. 3; ф. 684, оп. 1, спр. 3009, арк. 2-4; ЛННБ, ф. 3, спр. 76, арк. 67-70.

Завдяки детальнішому описові богослужбових книг їхній склад можна представити на прикладі Крехівської обителі. Літургіка тут охоплювала близько чверті книгозбірні, складаючи разом 25 примірників ${ }^{62}$. Серед Євангелій було два коштовно оздоблених напрестольних: «вдно в чо[р]номь аксамить з сръбро[м]», а дру-

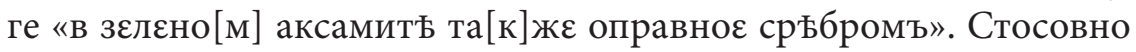
«عvли[й] новы $[\mathrm{x}] »$, то монастирю належало «двъ друку лво[в]ского», тобто львівські видання 1636 р. П’яту частину богослужбових книг становили Служебники: «Служєбниковъ піа[т] друкованы[х], два вилє $[$ н] скы $[x]$, києвъски $[x]$ два, піатьі[й] лво[в] ско[го] друку». Поза тим, монастирю належало чотири Апостоли: два «сло[в]іан[с]кого друку» ${ }^{63}$ і два рукописні. Провенієнція одного з них відома: це так званий «Крехівський апостол», пам’ятка XVI ст. у руському перекладі з коментарями на Апокаліпсис ${ }^{64}$. Другий рукописний «Апостоль стихами избраный» - це кодекс, оправлений, за даними Івана Огієнка, у 1581 р., а сам рукопис мав кальвіністське походження й був написаний у 1560-х рр. на Волині ${ }^{65}$. «Триоди[й] двъ друкованыъ

62 Детальніше про богослужбові книги Крехівського монастиря див.: Іван Альмес, «Богослужбові книги у Крехівському василіанському монастирі у другій половині XVIII ст.», Історія релігій в Україні: Науковий щорічник 1 (2014): 155-168.

${ }^{63}$ ЦДІА України у Львові, ф. 129, оп. 1, спр. 539, арк. 3, 4.

${ }^{64}$ Кириличні рукописні книги у фондах Львівської наукової бібліотеки ім. В. Стефаника НАН Украйни. Каталог (Львів, 2007), 1 (XI-XVI ст.): 76-78.

${ }^{65}$ Іван Огієнко, Українська тітературна мова XVI-го cm. і український крехівський Апостол (Варшава, 1930), 155, 158. 
киє[в]скиђ, постнаіа и цвътнаіа» ${ }^{66}$ - це київські видання $1627 \mathrm{i}$ 1631 pp..$^{67}$, а «Трїо[д] постнаіа кієвскаіа нова» - 1640 p. ${ }^{68}$ Знаходилась у Крехові і рукописна Мінея формату in folio, яку, за свідченням Антона Петрушевича, почав писати диякон Стефан у 1617 p. ${ }^{69}$ Книгозбірні також належав рукописний Устав, переписаний у Львові (не раніше 1630-х рр.) із московського видання 1611 р. друкаря Онисима Радишевського ${ }^{70}$. Серед решти крехівських рукописів варто згадати ілюстрований рукописний Ірмолой, переписаний у Золочеві ${ }^{71}$. Врешті, для читання Святого Письма можна було скористатися двома друкованими примірниками Біблії, ймовірно, острозького друку ${ }^{72}$.

Серед «нестандартних» книг Підгорецького монастиря заслуговують на увагу київське видання 1697 р. Канонів Богородиці ${ }^{73}$, а Теребовельського - Требник стрятинського друку 1606 р. та польськомовна Біблія (єдина книга, що тї зафіксовано як польську: «Biblia polska wielka») ${ }^{74}$. Невідомо, про яке саме видання йдеться, але, найімовірніше, - це Біблія у перекладі єзуїта Якуба Вуєка, що побачила світ у Кракові 1599 р. Врешті, окрім київських чи львівських видань, в інвентарях обох згаданих монастирів фіксується продукція віленської, чернігівської (див. далі) та московської друкарень, пор.: «Служєбникъ малы[й] вилє[н]ского друку», «ұал-

${ }^{66}$ ЦДІА України у Львові, ф. 129, оп. 1, спр. 539, арк. 3.

67 Яким Запаско, Ярослав Ісаєвич, Пам'ятки книжкового мистецтва. Каталог стародруків, виданих на Україні (Львів, 1981), 1 (1574-1700): № 160, 220.

${ }^{68}$ Каталог иерковнославянских рукописей и старопечатних книг кирилловского письма, находящихся на археологическо-библиографической выставке в Ставропигиальном заведении, укл. А. Петрушевич (Львов, 1888), 22.

${ }^{69}$ Антоній Петрушевич, Сводная Галицко-Русская летопись с 1600 по 1700 год (Львов, 1874), 51-52.

${ }^{70}$ Ігор Мицько, «Ідеологічна боротьба на Україні», 107.

${ }^{71}$ Каталог иерковно-словенских рукописей, 13.

${ }^{72}$ ЦДІА України у Львові, ф. 129, оп. 1, спр. 539, арк. 3зв.-4. У 1645 р. монастиреві було подаровано Острозьку Біблію, яка сьогодні зберігається у Національній бібліотеці у Варшаві: Katalog druków cyrylickich XV-XVIII wieku w zbiorach Biblioteki Narodowej, red. Z. Żurawińska, Z. Jaroszewicz-Pieresławcew (Warszawa, 2004), 24.

73 ЛННБ, відділ рукописів, ф. 3, од. зб. 76, арк. 67 зв.

${ }^{74}$ ЦДІА України у Львові, ф. 684, оп. 1, спр. 3009, арк. 2. 
тыра ин фолЂш то[л]коvанаіа моско[в]скаіа», «Трєбникъ ин фолЂш москоускїи» ${ }^{75}$.

Твори Отиів Церкви. «Обов’язкову» лектуру в монастирях східного обряду становила патристична спадщина ${ }^{76}$, що й не дивно, адже пієтет перед візантійською традицією був притаманний і трактатам

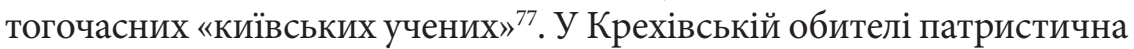
«колекція» складалась із 17 видань, з-поміж яких сім - це твори Йоана Золотоустого, наприклад, бесіди «На дъіаниіа ап[осто]льскиє двођ», тобто екзегетичні проповіді «Бесіди на діяння святих апостолів». Також у Крехові був основний святоотцівський трактат 3 патрології «Книга о священстві» (два примірники львівського друку 1614 р..$\left.^{78}\right)$. Згадується в інвентарі й «Маргарит» - збірка уставних повчань Золотоуста у двох друкованих примірниках та одному рукописному 1617 p. ${ }^{79}$. Праці Йоана Золотоустого знаходились також у книгозбірнях Львівського Святоонуфріївського, Підгорецького й Теребовельського монастирів. Зокрема, у першій зі згаданих обителей зберігалась «Една книга на паргаминъ наука, в нєи с[вя]таго Ишанна Златоустаго» ${ }^{80}$, тобто рукописний збірник повчань святителя. Про манускрипти «Златоустыи», а також «Бесъды Златоустаго» згадано і в описі бібліотеки Підгорецького монастиря ${ }^{81}$. Навіть у невеликій книгозбірні Теребовельської обителі були «Besiady na dzieie apostolskie» ${ }^{82}$, тобто вже згадувані «Бесіди на діяння святих апостолів» - ймовірно, примірник київського видання $1624 \mathrm{p}$.

Окрім Львівського монастиря, у решті з трьох досліджуваних книгозбірень представлено «Повчання» авви Дорофея - стародрук

75 ЛННБ, відділ рукописів, ф. 3, од. зб. 76, арк. 67 зв.

${ }^{76}$ Ігор Ісіченко, арх., Аскетична література Киӥвської Руси (Харків, 2005), 128.

${ }^{77}$ Наталя Сінкевич, «Сильвестр Косов - викладач Києво-Могилянського колегіуму: реконструкція навчальних курсів через призму інтелектуальних інтересів викладача», в Шлях у чотири століття. Матеріали Міжнародної наукової конферениї «Ad fontes - До джерел» до 400-ї річниці заснування Києво-Могилянської академії (12-14 жовтня 2015 року) (Київ, 2016), 46.

${ }^{78}$ Каталог кириличних стародруків Львівської наукової бібліотеки, 4: 20.

79 Ярослав Гординський, «Рукописи бібліотеки монастиря св. Онуфрія у Львові», Записки ЧСВВ т. 1, вип. 2-3 (Львів, 1925): 39.

${ }^{80}$ ЦДІА України у Львові, ф. 129, оп. 1, спр. 1033, арк. 3.

81 ЛННБ, відділ рукописів, ф. 3, од. 36. 76, 69-69 зв.

${ }^{82}$ ЦДІА України у Львові, ф. 684, оп. 1, спр. 3009, арк. 2. 
у Підгірцях ${ }^{83}$ та, скоріш за все, рукописний примірник у Теребовлі ${ }^{84}$. Що ж до Крехова, то тут було аж чотири примірники «Поученій» київського друку 1628 р. у перекладі з греки Памви Беринди (одну 3 цих книг подарував обителі Петро Могила $\left.{ }^{85}\right)$. Загалом же Крехівському монастирю належала показна підбірка творів східних Отців Церкви: Анастасія Синаїта, Йоана Ліствичника та Йоана Дамаскіна. Ймовірно, за назвою «Анастаси[й] горьі сина[й]скоъ книга» ховався список праці св. Анастасія «Питання і відповіді на різні теми», перекладеної церковнослов'янською ще в IX ст. (ця книга аж до середини XVI ст. виконувала у православній традиції функцію катехизису ${ }^{86}$ ). Хоч в інвентарі не подано назви книги Йоана Ліствичника, проте, поза сумнівом, ішлося про класичний твір візантійського аскетичного письменства «Ліствиця». Йоан Дамаскін був представлений у бібліотеці списком 1605 р. під назвою «Небеса», тобто однією із частин «Точного викладу православної віри». Могли тогочасні насельники Крехівського монастиря ознайомитись і з творами Єфрема Сиріна та Василія Великого. Зокрема, згадана в інвентарі «С[вя]т $\left[о\right.$ г]г Василиіа книга ${ }^{87}-$ це, можливо, «Книга о постничестві» острозького видання $1594 \mathrm{p}^{88}$.

83 «Дорофєи, друку»: ЛННБ, відділ рукописів, ф. 3, од. зб. 76, арк. 69.

${ }^{84}$ ЦДІА України у Львові, ф. 684, оп. 1, спр. 3009, арк. 2.

85 «... Пвтро[м] Могилою... до шбщижътїа инокшвъ Православны[х] по[д] послуш[ع]ство[м] Па[т]ріа[р]хи Ко[н]ста[н]тинополского въручимъ в Монастир Крехо[в]скъ[й]»: ЛННБ, відділ рідкісної книги, II ст. 2348, арк. 2-9 зв. Згадав Могила про монастир і в своєму тестаменті, заповівши частину коштів на Крехівський монастир. Після розпорядження щодо майна та справ він пише: якщо «розчисленого залишиться в убогій шкатулці моїй грошей готівкою, також у винах, медах... на добродійні справи в різних монастирях спільножитних..., що жодних прибутків не мають, тобто до Скиту, до Межигіря, до Тригіря, до Крехова, до Угорників, до Мгару, до Густині...». Цит. за: Аркадій Жуковський, Петро Могила й питання єдности церков (Київ, 1997), 295.

${ }^{86}$ Маргарита Корзо, «Русская катехитическая традиция XVII - первой половины XVIII в.: к постановке исследовательной задачи», в Человек в культуре русского барокко. Сборник статей по матер. межд. конф. ИФ РАН Москва, 28-30 сентября 2006 г. (Москва, 2007), 199.

${ }^{87}$ ЦДІА України у Львові, ф. 129, оп. 1, спр. 539, арк. 3 зв.

88 Зберігся примірник з Крехівської обителі із власницькими записами: Кириличні стародруки у фондах бібліотеки отців василіан при СвятоОнуфріївському монастирі у Львові XVI - XIX століть. Каталог, укладач Станіслав Волощенко (Жовква, 2015), 20-22. 
Якийсь із творів Василія Великого фіксується і в описі Теребовельського монастиря як «Basilij» ${ }^{89}$, а в 1679 р. вишневецький парох

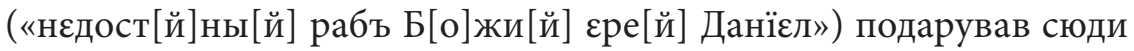
«во нравоученїє братїъ примірник «Книги о постничетві» щойно згаданого острозького друку 1594 p. ${ }^{90}$. Врешті, у конволюті початку XVII ст. Львівського монастиря під назвою «Макари[й $]{ }^{91}$ містились списки творів Макарія Єгипетського (IV ст.), слова Григорія Богослова тощо ${ }^{92}$. Тут же під назвою «Касиіань» ${ }^{93}$, найвірогідніше, був твір шанованого на Заході патриста Йоана Касіяна Римлянина (бл. 360 - 435). Святотцівську спадщину, хоч і скромно, представлено й у Підгорецькому монастирі. Окрім уже згаданих творів Йоана Золотоустого та авви Дорофея, тут фіксується московське видання «Повчань» Єфрема Сиріна та київське видання 1628 р. «Лимонара» Йоана Мосха («Луг духовний» чи патерик Синайський) ${ }^{94}$, тобто класична для східної монастирської традиції духовно-аскетична лектура.

Уживаними серед ченців були не лише повні твори, а й збірки виписів із творів Отців Церкви, соборних постанов тощо. Так, у крехівській книгозбірні знаходився список кінця XVI ст. перекладу з греки «Пандектів» Никона Чорногорця (Х ст.), переписаний Іваном Бонаревським з Підгір'я 95 (рукописний примірник цього твору під назвою «Никон» згадано також в описі книг Підгорецького монастиря $\left.{ }^{96}\right)$. Схожий за змістом рукопис XVI - XVII ст. «Пандектів» Антіоха (VI - VII ст.) був у Крехівській обителі ${ }^{97}$, а друкований

${ }^{89}$ ЦДІА України у Львові, ф. 684, оп. 1, спр. 3009, арк. 2.

${ }^{90}$ Каталог кириличних стародруків Львівської наукової бібліотеки, 2: 13.

${ }^{91}$ ЦДІА України у Львові, ф. 129, оп. 1, спр. 539, арк. 4

92 Гординський, «Рукописи бібліотеки монастиря св. Онуфрія у Львові», т. 3, вип.1-2: 45-47.

${ }^{93}$ ЦДІА України у Львові, ф. 129, оп. 1, спр. 539, арк. 3 зв.

94 «Ефрємъ ин кvа[р]то друку моско[в]ского», «Црбтникъ д[у]ховныи, друку»: ЛННБ, відділ рукописів, ф. 3, од. зб. 76, арк. 69.

${ }^{95}$ Кириличні рукописні книги у фондах, 324-325; Марта Боянівська, «Світські переписувачі книжок в українській книгописній культурі XV - середини XVII століть», Записки НТШ 233 (1997): 243.

96 «Никонъ ин фолъш писаныи»: ЛННБ, відділ рукописів, ф. 3, од. зб. 76, арк. 69.

97 Там само, од. зб. 798, 218 арк. 
примірник 1612 р. видання «Діоптри» Філіпа Мононтропа - у Підгорецькому монастирі ${ }^{98}$.

Житійна література. Особливою «популярністю» користувалися у досліджуваних монастирях Патерики та Прологи з оповідями про житія і діяння святих, що слугували чи не найкращим взірцем християнської праведності. У Львівському Святоонуфріївському монастирі згадано, зокрема, «Три прологи на паргаминъ» ${ }^{99}$, тобто якісь старі списки, а в Крехові фіксується аж п’ять книг агіографічного характеру, серед яких рукописні «Житииа с[вя]тьі $[\mathrm{x}] »^{100}$ та два Прологи - один кінця XVI ст. за березень-серпень ${ }^{101}$, а другий розширеної версії за вересень-лютий, переписаний єреєм Симеоном у 1621 p. ${ }^{102}$. У цій же книгозбірні був конволют під назвою «Льмонарь сиріч Цвътникь духовный и прочая», який під спільною обкладинкою містив один рукопис і три стародруки: 1) власне «Льмонарь», тобто Синайський патерик, переписаний із київського друку 1628 р.; 2) «Вьршь зь Трагодіи Хрістось пасхонь» (Львів, 1630); 3) «Діоптра» (Єв’€, 1612) - збірник енциклопедичного змісту IX ст., укладений візантійським монахом Філіпом Пустельником (Мононтропом); 4) «Духовныи бесъды святого отца нашего Макарія» (Вільно, 1627). На окрему увагу серед цих друків заслуговує невелике (36 с.) виданняпереказ твору «Хрістось пасхонь» Григорія Богослова ${ }^{103}$, на чистих аркушах якого невідомий чернець написав «для пам'яти» коротку «Кройнику» ${ }^{104}$. Тут же, в Крехові, згадано книгу «Мъта[р]ство д[у]

${ }^{98}$ Там само, ф. 3, од. зб. 76; Л. Ситникова, «Виленские кирилловские издания конца XVI - первой воловины XVII в. во львовских собраниях», в Федоровские чтения 1982 (Москва, 1987), 85.

${ }^{99}$ ЦДІА України у Львові, ф. 129, оп. 1, спр. 1033, арк. 3.

${ }^{100}$ Там само, спр. 539, арк. 3 зв.

${ }^{101}$ Кириличні рукописні книги у фондах, 343-344.

102 Марина Чистякова, «Рукописные Прологи Львовской национальной научной библиотеки Украины имени В. Стефаника», Записки Львівської національної наукової бібліотеки України імені В. Стефаника: зб. наук. пр. 3 (19) (2011): 353-354.

${ }^{103}$ Василь Щурат виявив цей конволют у Крехові в 1907 р.: Василь Щурат, «Хрістос пасхон. Львівські віршовані діалоги з 1630 р.», Записки НТШ 117-118 (1913): 139.

${ }^{104}$ Аристарх Крижановський, «Руська «кройника» з XVII в.», Записки НTШ 62 (1904): 1-3 (Miscellanea); Дмитро Вирський, Роксолани серед Сарматів: річпосполитська історіограбія України (кінець XV ст. - 1659) (Київ, 2013), 186. 
ховноє» - очевидно, список оповіді про митарства преподобної Феодори з житія Василія Нового.

У Підгорецькій обителі агіографічну літературу представлено друкованим примірником «Патєрикъ пєчєрскіи друку кїєүского» (очевидно, видання 1661 р.; у Теребовлі цю саму (?) книжку названо «Pateryk Pieczarski» ${ }^{105}$ ), а також польськомовною працею «Жиvоты с[вя]тыхъ $\omega[$ те]цъ, ин фолъ $\omega$ друкоvаныи». Це, скоріш за все, відомі «Żywoty świętych» єзуїта Петра Скарги, що їх друкували у форматі in folio. Згадано в Підгорецькому інвентарі й список під назвою «Патєрикъ скицкїи» ${ }^{106}$ - це т. зв. «Манявський збірник» 3 текстами житія засновника Скиту Манявського Йова Княгиницького, а також «Завіту духовного» й «Уставу чернечого» ${ }^{107}$. Фіксуються в підгорецькій книгозбірні й Прологи (московське видання за березень-вересень та дві рукописні частини на цілий рік), а також примірник кутеїнського видання 1637 р. «Гисторія...» про Варлаама та Йоасафа: її у переліку названо «Варлаам» ${ }^{108}$.

Проповідницька література. Як один із найважливіших засобів християнського напучення, проповідництво набуло особливого поширення у період реформаційних рухів та Контрреформації ${ }^{109}$. В ухвалах Тридентського собору 1545-1563 рр. виголошення проповідей на неділі й празники потрактовано як обов'язок священиків, ченців та єрархів ${ }^{110}$. Активізація проповідницьких практик спостерігається з кінця XVI ст. і в українських православних осередках ${ }^{111}$.

${ }^{105}$ ЦДІА України у Львові, ф. 684, оп. 1, спр. 3009, арк. 2.

106 ЛННБ, відділ рукописів, ф. 3, од. 36. 76, арк. 69-70.

107 Публікацію Скитського патерика за списком Підгорецького монастиря здійснили дослідники Прикарпатського національного університету ім. В. Стефаника: Великий Скит у Карпатах: у 3-х т., т. 1: Патерик Скитський. Синодик (Івано-Франківськ: Манукрипт-Львів, 2013).

108 «Прологъ ин фольш дру[ку] моско[в]ского на [6] м[ъся]цєи, Ф ма[р] та до септемvріїа», «Прологоvъ дvа писаны[х] на [12] м[ъся]цєи», «Варлаамъ, друку»: ЛННБ, відділ рукописів, ф. 3, од. зб. 76, арк. 683в.-69.

${ }^{109}$ Kazimierz Panuś, Historia kaznodziejstwa (Kraków, 2007), 195; Marzanna Kuczyńska, Ruska homiletyka XVII wieku w Rzeczpospolitej. Ewolucja gatunku specyfika funkcjonalna (Cyryl Stawrowiecki: Ewangelia pouczająca. Rachmanów 1619; Joannicjusz Galatowski: Klucz rozumienia. Kijów 1659) (Szczecin, 2004).

${ }^{110}$ Panuś, Historia kaznodziejstwa, 214-215, 231-235.

${ }^{111}$ Галина Чуба, Українські рукописні учительні Євангелія. Дослідження, каталоги, описи (Львів, 2011). 
До необхідного інструментарію проповідника належало не лише Святе Письмо, а й збірники проповідей, повчальних оповідок тощо. Тому наявність гомілетичних видань у складі парафіяльних чи монастирських книгозбірень опосередковано свідчить про активне душпастирство, а сама номенклатура книг відображає характер проповідницької діяльності.

В аналізованих монастирських книжкових зібраннях представлено різноманітні гомілетичні збірники, навіть постили (з лат. post illa verba - після цих слів), тобто проповіді екзегетичного змісту, більш характерні для католицької і протестантської традиції. 3окрема, в описі Крехівської книгозбірні згадується «Пости[л]ліа ву[й] ковъскаіа великаіа старо[го] друку» ${ }^{112}$, тобто одне з краківських видань проповідей відомого польського єзуїта Якуба Вуєка (1541-1597). Паралельно в монастирі уживали традиційне для східнохристиянської традиції джерело напучення - Учительне Євангеліє. Зокрема, за даними Антона Петрушевича, в Крехові був примірник крилоського видання цієї книжки 1606 p. ${ }^{113}$, а також рукописне Учительне Євангеліє, переписане єреєм Тимофієм у 1623 p. ${ }^{114}$. Натомість в описі Львівського Святоонуфріївського монастиря кінця XVI ст. проповідницьку традицію представлено лише чотирьома примірниками рукописних Учительних Євангелій ${ }^{115}$.

Деякі із зібрань проповідей «київських учених» другої половини XVII ст. зберігались у Теребовельському монастирі. Укладач інвентаря записав позиції «Miecz», «Klucz rozumienia» та «Nowe niebo» ${ }^{116}$, не вказавши імена авторів, але ченці з самими книгами були, слід гадати, ознайомлені. Дві з цих позицій — це твори одного з найпопулярніших тогочасних авторів Київської митрополії Йоаникія Галятовського († 1688). Мова про збірку проповідей «Ключ разумънія» (найімовірніше, примірник львівського видання 1663 або 1665 р.), а також компендіум богородичних чуд «Небо новоє» з багатьма апокрифічними та легендарними оповідками. Що ж до позиції «Miecz», то це «Меч духовный», збірник 55 проповідей на

\footnotetext{
112 ЦДІА України у Львові, ф. 129, оп. 1, спр. 539, арк. 3 зв.

${ }^{113}$ Каталог иерковно-словенских рукописей, 25.

${ }^{114}$ Петрушевич, Сводная Галицко-Русская летопись с 1600 по 1700 год, 60.

115 ЦДІА України у Львові, ф. 129, оп. 1, спр. 1033, арк. 3.

${ }^{116}$ ЦДІА України у Львові, ф. 684, оп. 1, спр. 3009, арк. 2.
} 
перехідні празники та неділі чернігівського архиєпископа Лазаря Барановича, вчителя Йоаникія Галятовського, виданий друком у Києві 1666 p. ${ }^{117}$.

Різноманітніше та, сказати би, більш «комплексно» представлено творчість «київських учених» у Підгорецькому монастирі, й то не лише збірками проповідей, хоч їх було таки найбільше. Так, окрім «Ключа разумінія» Галятовського, в інвентарі згадано ще два його твори: «Алфабєтумъ друкоvаныи» та «Скарбница друкоvанађ». Перший, виданий у Чернігові 1681 p. «Alphabetum albo Słownik rozmaitym heretykom niewiernym», являв собою своєрідний каталог 3 характеристикою ранньохристиянських та нових єресей ${ }^{118}$, а другий («Скарбница потребная») - це опублікована в Новгороді-Сіверському 1676 р. історія ікони Матері Божої чернігівського Єлецького монастиря та опис її чудес ${ }^{119}$. Врешті, окрім щойно згаданого «Меча духовного» Лазаря Барановича, у Підгірцях був його польськомовний віршований твір «W wieniec Bożey Matki» (Чернігів, 1680). Поза тим, у Підгірцях фіксуються дві друковані праці ще одного вихованця Києво-Могилянської колегії, далі проповідника Києво-Печерської лаври Антонія Радивиловського († 1688 р.), а саме: книга його гомілій на всі господські й богородичні празники та дні святих «Огородок Маріи Богородицы» (Київ, 1676) та збірка 115 проповідей на неділі й перехідні празники «Вьнец Христов» (Київ, $1688)^{120}$. Врешті, доповнював підбірку творів «київських учених» Підгорецького монастиря друкований примірник «Миру з Богом чоловіку» Інокентія Гізеля - перший трактат з моральної теології у православній традиції.

Інші «тематичні рубрики» у досліджуваних монастирських книгозбірнях представлено поодинокими працями. Так, з-поміж книг екзегетичного характеру у Крехівській бібліотеці знаходився рукописний «Толковий псалтир» $(1612 \text { р. })^{121}$, переписаний белзь-

${ }^{117}$ Ігор Ісіченко, арх., Історія украӥнської літератури: епоха Бароко (XVIIXVIII cm.). Навчальний посібник (Львів, 2011), 207-208.

118 Детальніше про цей трактат див.: Наталя Яковенко, У пошуках Нового неба, 313-325.

119 Там само, 70.

${ }^{120}$ Про ці твори ширше див.: Ігор Ісіченко, арх. Історія української літератури, 214-215.

${ }^{121}$ Каталог иерковно-словенских рукописей, 12. 
ким священиком Григорієм Терлецьким ${ }^{122}$. У 1672 р. міщанин Іван Синдеровський подарував монастирю в Теребовлі список тлумачень Феофілакта Болгарського ${ }^{123}$ (цю книгу укладач інвентаря записав як «Theofilak» $\left.{ }^{124}\right)$. Церковне право представляли у книгозбірнях Номоканони. Так, у Крехові зберігалось їх аж три, серед них рукописний півуставний примірник кінця XVI ст. ${ }^{125}$ У Підгірцях була рукописна книга «Праvила с[вя]тыхъ $ळ[$ те]цъ, ин фолъ писаныи» ${ }^{126}$, тобто теж Номоканон. Вірогідно, йшлося про той примірник, що його у 1689 р. о. Парфеній придбав від львівського міщанина (сьогодні він зберігається у рукописних колекціях Національної бібліотеки у Варшаві ${ }^{127}$ ). В інвентарі 1579 р. Святоонуфріївської Львівської обителі Номоканона не згадано, проте відомо, що тут був рукописний примірник «Собори святих отецъ», який зберігся до сьогодні ${ }^{128}$.

Плутану передісторію мала згадана у підгорецькій книгозбірні праця під назвою «Книжокъ дvъ писаныхъ Домєцкого $\omega$ цуъчєню законному» ${ }^{129}$. У 1689 р. настоятель Підгорецького монастиря о. Парфеній Ломиковський, перебуваючи в Москві за дорученням львівського владики Йосифа Шумлянського, отримав у подарунок дві рукописні книги: «Куновїш́нъ или из'́бражєнїє єvлского иноч-

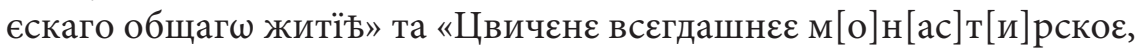
іакш законникъ маєтъ цвичити съ во с[вя]томъ стану иночєско[м]», укладені в 1683 р. «трудомъ Гаврїила Домєцкогш» ${ }^{130}$. Домецький († після 1708), вихідець з України, був на той час архимандритом Московського Симонового (1676-1690) та Новгородського Юрі-

${ }^{122}$ Мицько, Ідеологічна боротьба на Україні, 106.

123 ЛННБ, відділ рукописів, ф. 3, од. зб. 75, арк. 8-15.

${ }^{124}$ ЦДІА України у Львові, ф. 684, оп. 1, спр. 3009, арк. 2.

${ }^{125}$ Каталог иерковно-словенских рукописей, 11.

126 ЛННБ, відділ рукописів, ф. 3, од. зб. 76, арк. 69.

${ }^{127}$ Корогодина, Кормчая книга в Галиции, 151.

128 ЛННБ, відділ рукописів, ф. 3, од. зб. 415; Корогодина, Кормчая книга в Галиции, 148.

129 ЛННБ, відділ рукописів, ф. 3, од. зб. 76, арк 69 зв.

${ }^{130}$ Конволют $з$ творами о. Гавриїла сьогодні зберігається у відділі рукописів ЛННБ, і в ньому містяться три твори: крім згаданих, це ще «Наука обшая о смерті». Усі вони написані Домецьким та подаровані ним до Підгірців у 1695 р.: ЛННБ, відділ рукописів, ф. 3, од. зб. 302. 
йового монастирів ${ }^{131}$. Переписана ним книга являла собою устав спільножитного монастиря та духовні настанови його насельникам, адресовані російським ченцям. Питання, чи в Підгірцях використовували ці повчання та приписи «на практиці», залишається нині відкритим. Утім, підгорецькі монахи могли ознайомитися також із західною традицією аскетичного життя за польськомовним виданням «Uspokojenie w Bogu» ${ }^{132}$, що містило 20 роздумів про чернече життя єзуїта Теофіла Рутки (серед іншого, тут описано культ серця Ісусового $\left.{ }^{133}\right)$.

Книги світського змісту представлено в досліджуваних монастирських бібліотеках лише поодинокими виданнями. Наприклад, у Крехівській книгозбірні це всього три книжки: дві граматики Лаврентія Зизанія віленського видання 1596 р. («Зизани[й] кни[ж] ка, гра[м]матьіка грє[ц]кословє[н]скаіа»), «Лексикон славеноросскій» Памви Беринди (Київ, 1627) та «Синопсис[с] по[л]ски[й]

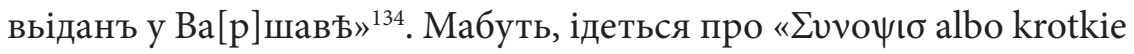
spisanie praw... na kształt rocznych dzieiow» - збірку привілеїв «руського народу», що іï надрукувало Віленське братство у 1632 p. ${ }^{135}$, a укладач інвентаря просто невірно вказав місце видання. Стосовно тематичного спрямування цієї полемічної праці, то вона, за висловом Дмитра Вирського, являла собою «екстракт історії православної церкви на річпосполитській Русі» ${ }^{136}$. В інвентарі Підгорецького

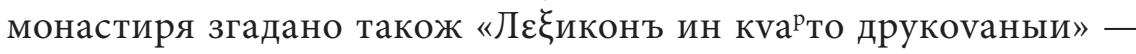
найімовірніше, щойно згаданий «Лексикон» Памви Беринди. Не вповні ясно, про що йдеться у позиції «Над гробокъ Балабаноvъ ин фолъ $\omega$ друку кїєүского» ${ }^{137}$ : можливо, так було виокремлено присвяту митрополитові Діонісію Балабану з передмови до жалобного панегірика «Столп цнот» на смерть Сильвестра Косова (Київ, 1658).

${ }^{131}$ Кольбух, Книгозбірня Підгорецького монастиря, 397.

${ }^{132}$ В інвентарі записано як «Успокоєнїє v Бгу, друкоvаноє»: ЛННБ, відділ рукописів, ф. 3, од. зб. 76, арк. 70.

${ }^{133}$ Ludwik Grzebień, «Rutka Teofil», w Polski słownik biograficzny (Warszawa, 1991-1992), 33: 203.

${ }^{134}$ ЦДІА України у Львові, ф. 129, оп. 1, спр. 539, арк. 4.

${ }^{135}$ Karol Estreicher, Bibliografia polska 8 (1882): 204.

${ }^{136}$ Вирський, Роксолани серед Сарматів, 178.

137 ЛННБ, відділ рукописів, ф. 3, од. зб. 76, арк. 69 зв. 
$* * *$

Аналіз оглянутих у цій статті чотирьох монастирських книгозбірень Львівської єпархії не дозволяє впевнено окреслити всі особливості книжкової культури православних монастирів, проте, як відомо, загальне виявляється в окремому, і це дає підстави для певних узагальнень. Отож загалом обителям Львівської єпархії належали невеликі за обсягом книжкові зібрання, коли порівняти ïx із тогочасними католицькими кляшторами. Приміром, найбільше з відомих у Крехові налічувало лише бл. 100 томів, а найкраще укомплектованою тематично виглядає Підгорецька книгозбірня, що зумовлювалося персональним чинником - ігуменством о. Парфенія Ломиковського. Утім, в усіх випадках ішлося про «руські бібліотеки», тобто переважно, а подекуди практично повністю, кириличні зібрання, хоч у цей самий час київська учена еліта послуговувалась здебільшого латинськими виданнями та вже обходилась без польського посередництва ${ }^{138}$. Відтак, перед нами точно не обителі, що їх можна було би кваліфікувати як приклади «Polonica Orthodoxa» ${ }^{139}$, а їхніх ченців, потенційних читачів цих книг, аж ніяк не зарахуєш до складу тогочасної західної respublica litterarum ${ }^{140}$.

Разом $з$ тим, хоч склад будь-якої бібліотеки, за спостереженням соціологів культури читання, не конче складається з книжок, що їх читають чи збираються прочитати ${ }^{141}$, проте номенклатура збірки все-таки відображає певні преференції власника. Lectio Orthodoxorum православних монастирів Львівської єпархії XVII ст. - це, окрім богослужбових книг, своєрідна «тріада»: святоотцівська духовно-аскетична спадщина, житійна (агіографічна) та проповідницька література. Такий «класичний» набір лектури, збережений щонайменше до кінця XVII ст., не видається чимось особливим. Як зазначає Марчело Гардзаніті, «світ Slavia Orthodoxa був пов'язаний із найдавнішою християнською традицією, далекою

138 Яковенко, У пошуках Нового неба, 11.

${ }^{139}$ Jakub Niedżwiedż, Kultura literacka Wilna (1323-1655): retoryczna organizacja miasta (Kraków, 2012), 45.

140 Детальніше про цей концепт див.: P. Fiska, I. Peper, Th. Stockinger, Th. Wallnig, «Res Publica Litteraria», in Geschichte der Buchkultur, Bd. 7: Barock, ed. by Ch. Gastgeber, E. Klecker (Graz, 2010), 129-160.

${ }^{141}$ Roger Chartier, The Order of Books. Readers, Authors, and Libraries in Europe between the Fourteenth and Eighteenth Centuries (Stanford, 1994), 19. 
від схоластичного диспуту... Святе Письмо, яке промовлялося (а точніше - співалося) під час Літургії, являло собою неподільне ціле з екзегезою Отців Церкви, стійко закріпленою у гомілетичних збірниках, що були організовані за порядком церковних празників» ${ }^{142}$. Подібний склад книжкових зібрань спостерігається і в тогочасних московських монастирях ${ }^{143}$ та болгарських обителях, де у XVII ст. здебільшого зберігалися рукописні, а не друковані книги - літургійні, «дамаскини», збірки проповідей ${ }^{144}$. Натомість «читацький канон» василіян у монастирях Львівської єпархії XVIII ст., особливо в другій його половині, вже рішуче інакший за тематичними преференціями ${ }^{145}$. Хоч тут, як і в римо-католицьких монастирських бібліотеках, далі переважають Святе Письмо, коментарі до нього і твори Отців, а також проповідницька література, проте неодмінними стають катехізиси, трактати з казуїстики, порадники для медитацій і реколекцій тощо ${ }^{146}$.

В аналізованих православних книгозбірнях, як уже зазначалося, практично немає світської літератури, зокрема античної спадщини - творів давньогрецьких та римських авторів, на вивчення яких спиралася гуманістична система освіти, серед іншого, й у

142 Марчелло Гардзанити, «"Учительное Евангелие” Мелетия Смотрицкого в контексте церковно-славянской традиции евангельской гомілетики и проблема перевода евангельских чтений», in Traduzione e rielaborazione nelle letterature di Polonia, Ucraina e Russia XVI - XVIII secolo (Alessandria, 1999), 167. Цит за: Яковенко, У пошуках Нового неба, 202.

${ }^{143}$ Max J. Okenfuss, The Rise and Fall of Latin Humanism in Early-Modern Russia: Pagan Authors, Ukrainians, and the Resiliency of Muscovy (Leiden; New York; Köln, 1995), 30.

${ }^{144}$ Dennis P. Hupchick, The Bulgarians in the Seventeenth Century. Slavic Orthodox Society and Culture under Ottoman Rule (Jefferson; London, 1993), 187-188.

145 Пор.: Іван Альмес, «Коло читання ченців Львівської єпархії другої половини XVIII ст.: бібліотеки василіанських ієромонахів Юстина Ілляшевича та Йосафата Лозінського», Вісник Львівського університету. Серія книгознавство, бібліотекознавство та інбормаційні технологіi 11 (2016-2017) (у друці).

${ }^{146}$ Див., наприклад: Claude Jolly, «Unité et diversité des collections religieuses», in Histoire des bibliothèques françaises, vol. 2: Les Bibliothèques sous l'Ancien Régime (1530-1789), sous la dir. de Claude Jolly (Paris: Promodis-Éd. du Cercle de la Librairie, 1988), 12. 
церковних закладах ${ }^{147}$. Це опосередковано повідомляє не тільки про освітній рівень ченців, а й про брак «попиту» - відсутність «практичної» потреби у такій лектурі. Це помітно відрізняє досліджувані монастирі Львівської єпархії від тих православних обителей, при яких діяли навчальні осередки - наприклад, київський печерський монастир. Чи може це слугувати одним зі свідчень, що для насельників цих монастирів основною залишалася молитва, а не «інтелектуальна праця» - основна, за висловом Ульріха Леенера, для т. зв. «просвічених ченців» ${ }^{148}$ ? Чи специфічний склад і невеликі обсяги книжкових зібрань можуть виступати одним із аргументів, аби розглядати ці монастирі як місця, де панував lex orandi, тоді як інтелектуальна активність не сприймалася за необхідну? Можливо й так, хоч за браком джерел складно простежити, наскільки ревно ченці дотримувалися приписів монашого життя та виконували аскетичні практики, хоч принаймні у двох з-поміж аналізованих обителей - Крехівській та Підгорецькій - устави передбачали сувору аскезу. Але в ширшому плані ці питання поки що залишаються без відповіді - особливо на тлі того зламу, який ми помічаємо в наступному столітті, коли київські монастирські книгозбірні постають як переважно латино-польські, однак і далі зберігають східну традицію церковних богослужінь та монастирського побуту. Завершуючи додам, що розумію обмеженість та спрощеність запропонованих у цій статті моделювань, проте створення певних моделей, як відомо, $€$ одним зі способів, за допомоги яких можна відповісти на поставлені питання чи, принаймні, чіткіше їх сформулювати.

${ }^{147}$ Craig Kallendorf, The Virgilian Tradition: Book History and the History of Reading in Early Modern Europe (Aldershot, 2007), ix.

${ }^{148}$ Ulrich Lehner, Enlightened Monks: the German Benedictines, 1740-1803 (Oxford, 2011), 30. 


\section{Bibliography}

Almes, Ivan. «Bohosluzhbovi knyhy u Krekhivskomu vasylianskomu monastyri u druhii polovyni XVIII st.» Istoriia relihii v Ukraini: Naukovyi shchorichnyk 1 (2014): 155-168.

Almes, Ivan. «Do istorii formuvannia knyhozbiren monastyriv Lvivskoi yeparkhii v druhii polovyni XVII — seredyni XVIII st.» Istoriia relihii v Ukraini: Naukovyi shchorichnyk 1 (2015): 83-98.

Almes, Ivan. «Do istorii Krekhivskoi monastyrskoi biblioteky pershoi polovyny XVII st.» in Pravoslavia v Ukraini: Zbirnyk materialiv III Vseukrainskoi naukovoi konferentsii. 2: 386-397. Kyiv, 2013.

Almes, Iwan. "Źródła do historii bibliotek klasztornych eparchii lwowskiej XVII-XVIII wieku. Inwentarze bazyliańskiego monasteru w Krechowie». In Textus et studia, pod. red. M. Hałaburdy, J. Szczepaniaka. 3: 7-27. Kraków, 2015.

Arkhiv Iugo-Zapadnoi Rossii, izdavaiemyi Komisiieiu dlia razbora drevnikh aktov pri kievskom, podolskom i volynskom general-gubernatore. P. 1, vol. 10. Kiev, 1904.

Beales, Derek. Prosperity and Plunder. European Catholic Monasteries in the Age of Revolution, 1650-1815. Cambridge, 2003.

Bochkovska, Valentyna. "Istoriia Pochaivskoho monastyria u vizytatsiiakh XVIII - pershoi chverti XIX st.» Rukopysna ta knyzhkova spadshchyna Ukrainy 13 (2009): 24-25.

Boianivska, Marta. "Svitski perepysuvachi knyzhok v ukrainskii knyhopysnii kulturi XV - seredyny XVII stolit». Zapysky NTSh 233 (1997): 239-250.

Brad, Gregory S. The Unintended Reformation. How a Religious Revolution Secularized Society. Cambridge; Massachusetts; London, 2012.

Burke, Peter. Społeczna historia wiedzy. Warszawa, 2016.

Charipova, Liudmyla. Latin Books and the Eastern Orthodox Clerical Elite in Kiev, 1632-1780. Manchester and New York: Manchester University Press, 2006.

Chartier, Roger. The Order of Books. Readers, Authors, and Libraries in Europe between the Fourteenth and Eighteenth Centuries. Stanford, 1994.

Chuba, Halyna. Ukrainski rukopysni uchytelni Yevanheliia. Doslidzhennia, katalohy, opysy. Lviv, 2011.

Chystiakova, Marina. «Rukopisnyie Prolohi Lvovskoi natsyonalnoi nauchnoi bibliotieki Ukrainy imieni V. Stiefanyka». Zapysky Lvivskoi 
natsionalnoi naukovoi biblioteky Ukrainy imeni V. Stefanyka: zb. nauk. pr. 3 (19) (2011): 353-354.

Derwich, Marek. «Monastycyzm w Polsce średniowiecznej i nowożytnej. Uwagi terminologiczne». In Christianitas et cultura Europeae. Ksiega Jubileuszowa profesora Jerzego Kłoczowskiego. 1: 255-259. Lublin, 1998.

Dovha, Larysa. Systema tsinnostei v ukrainskii kulturi XVII stolittia (na prykladi teoretychnoi spadshchyny Inokentiia Gizelia). Kyiv; Lviv, 2012.

«Dukhovnyi zavit iieroskhymonakha Ioila ihumena y osnovatelia Krekhovskoho monastyria 1638 goda». In Naukovyi sbornyk, izdavaiemyi literaturnym obshchestvom Halytsko-Russkoi Matytsy. Hod izdaniia chetvertyi 1868. I-IV: 321-334. Lvov, 1869.

Dziuba, Olena, and Frys, Vira. «Biblioteky Ukrainy». In Istoriia ukrainskoi kultury u 5 tomakh. Vol. 3: Ukrainska kultura druhoi polovyny XVII-XVIII st., 814-832. Kyiv, 2003.

Encyclopedia of Monasticism. Vol. 2. Chicago; London, 2000.

Evans, G. R. The History of Monasticism. The Western Tradition. London; New York, 2016.

Fiska P., Peper I., Stockinger Th., and Wallnig Th. «Res Publica Litteraria». In Geschichte der Buchkultur. Bd. 7: Barock, ed. by Ch. Gastgeber, E. Klecker, 129-160. Graz, 2010.

Grzebień, Ludwik. «Rutka Teofil». In Polski słownik biograficzny. 33: 203-204. Warszawa, 1991-1992.

Heneralni vizytatsii tserkov i monastyriv Volodymyrskoi uniinoi yeparkhii kintsia XVII - pochatku XVIII stolit: Knyha protokoliv ta okremi opysy, edited by A. Gill, I. Skochylias. Lviv; Liublin, 2012.

Hingley, Sheila. «Ecclesiastical Libraries: Libraries for the Higher Clergy». In The Cambridge History of Libraries in Britain and Ireland, edited by E. Leedham-Green, T. Webber. Cambridge, 2006.

Hordynskyi, Yaroslav. «Rukopysy biblioteky monastyria sv. Onufriia u Lvovi». Zapysky ChSVV vol. 1, issue 2-3 (Lviv, 1925): 234-272.

Hupchick, Dennis P. The Bulgarians in the Seventeenth Century. Slavic Orthodox Society and Culture under Ottoman Rule. Jefferson; London, 1993.

Inokentii Gizel. Vybrani tvory u 3 tomakh. Book 1, vol. 1. Kyiv; Lviv, 2012.

Isaievych, Iaroslav. Voluntary Brotherhood. Confraternities of Laymen in Early Modern Ukraine. Edmonton; Toronto, 2006. 
Isichenko, Ihor, arkh. Istoriia ukrainskoi literatury: epokha Baroko (XVII-XVIII st.). Navchalnyi posibnyk. Lviv, 2011.

Isichenko, Ihor, arkh. Asketychna literatura Kyivskoi Rusy. Kharkiv, 2005.

Jolly, Claude. «Unité et diversité des collections religieuses». In Histoire des bibliothèques françaises. Vol. 2: Les Bibliothèques sous l'Ancien Régime (1530-1789), sous la dir. de Claude Jolly, 11-27. Paris: Promodis-Éd. du Cercle de la Librairie, 1988.

Kallendorf, Craig. The Virgilian Tradition: Book History and the History of Reading in Early Modern Europe. Aldershot, 2007.

Katalog druków cyrylickich XV-XVIII wieku w zbiorach Biblioteki Narodowej, red. Z. Żurawińska, Z. Jaroszewicz-Pieresławcew. Warszawa, 2004.

Kataloh kyrylychnykh starodrukiv Lvivskoi naukovoi biblioteky im. V. Stefanyka NAN Ukrainy. Issue 3: Vydannia drukaren Lvova: Mykhaila Slozky, Arseniia Zhelyborskoho, Yosyfa Shumlianskoho, monastyria sv. Yura. Lviv, 2000.

Katalog tserkovnoslavianskykh rukopisei i staropiechatnykh knig kirillovskogo pisma, nakhodiashchikhsia na arkhieologichesko-bibliograficheskoi vystavkie $v$ Stavropigialnom zaviedienii, compiled by A. Petrushevych. Lvov, 1888.

Kmet, Vasyl. «Inventari Uspenskoi ta Sviatoonufriivskoi monastyrskoi tserkvy u Lvovi 1579 r.» Visnyk Lvivskoho natsionalnoho universytetu. Seriia istorychna 35 (2000): 494-510.

Kolbukh, Mariia. «Knyhozbirnia Pidhoretskoho monastyria: istoriia formuvannia». Zapysky Lvivskoi natsionalnoi naukovoi biblioteky Ukrainy imeni V. Stefanyka: zb. nauk. pr. 3 (19) (2011): 394-421.

Korogodina, Maria. Kormchaia kniga v Galitsyi (XVI - nachalo XVII veka). Sankt-Peterburg: BAN, 2015.

Korzo, Margarita. «Russkaia katekhiticheskaia traditsyia XVII — pervoi poloviny XVIII v.: k postanovkie issliedovatielnoi zadachw». In Chieloviek v kulturie russkogo barokko. Sbornik statiei po mater. miezhd. konf. IF RAN, Moskva, 28-30 sientiabria 2006 g., 199-207. Moskva, 2007.

Koshil, Oksana, and Ulianovskyi, Vasyl. Starozhytnia biblioteka Mykhailivskoho Zolotoverkhoho monastyria: sproba rekonstruktsii kyrylychnoi zbirky. Kyiv, 2008.

Kryzhanovskyi, Arystarkh. «Ruska "kroinyka" z XVII v.» Zapysky NTSh 62 (1904): 1-3 (Miscellanea). 
Kuczyńska, Marzanna. Ruska homiletyka XVII wieku w Rzeczpospolitej. Ewolucja gatunku - specyfika funkcjonalna (Cyryl Stawrowiecki: Ewangelia pouczająca. Rachmanów 1619; Joannicjusz Galatowski: Klucz rozumienia. Kijów 1659). Szczecin, 2004.

Kukushkina, Margarita. Monastyrskiie bibliotieki Russkogo Sieviera. Ochierki po istorii knizhnoi kultury XVI - XVII vekov. Leningrad, 1977.

Kyrylychni rukopysni knyhy u fondakh Lvivskoi naukovoi biblioteky im. V. Stefanyka NAN Ukrainy. Kataloh. Vol. 1 (XI-XVI st.). Lviv, 2007.

Kyrylychni starodruky $u$ fondakh biblioteky ottsiv vasylian pry SviatoOnufriivskomu monastyri u Lvovi XVI-XIX stolit. Kataloh, compiled by Stanislav Voloshchenko. Zhovkva, 2015.

Lehner, Ulrich. Enlightened Monks: the German Benedictines, 17401803. Oxford, 2011.

Luppov, Sergei. Kniga v Rossii v XVII viekie. Leningrad, 1970.

Lvivska natsionalna naukova biblioteka Ukrainy im. V. Stefanyka NAN Ukrainy, viddil ridkisnoi knyhy, II st. 2348; II st. 2361; II st. 30465.

Lvivska natsionalna naukova biblioteka Ukrainy im. V. Stefanyka NAN Ukrainy, viddil rukopysiv, f. 3, od. zb. 10, 132, 302, 415, 75, 76, $798,815$.

Mytsko, Ihor. «Ideolohichna borotba na Ukraini v XVII st. i formuvannia ta sklad bibliotek». In Bibliohrafichna informatsiia $i$ suchasnist: zbirnyk naukovykh prats, 102-111. Kyiv, 1981.

Natsionalnyi muzei u Lvovi imeni Andreia Sheptytskoho, Rkl-141, Rkk-681.

Niedźwiedź, Jakub. Kultura literacka Wilna (1323-1655): retoryczna organizacja miasta. Kraków, 2012.

Ohiienko, Ivan. Ukrainska literaturna mova XVI-ho st. i ukrainskyi krekhivskyi Apostol. Varshava, 1930.

Okenfuss, Max J. The Rise and Fall of Latin Humanism in EarlyModern Russia: Pagan Athors, Ukrainians, and the Resiliency of Muscovy. Leiden; New York; Köln, 1995.

Panuś, Kazimierz. Historia kaznodziejstwa. Kraków, 2007.

Paszkiewicz, Urszula. Cathalogus cathalogorum. Inwentarze i katalogi bibliotek z ziem wschodnich Rzeczypospolitej od XVI wieku do 1939 roku. T. 1-2. Warszawa, 2015.

Pawłyszyn, Andrij. «Prawosławne i unickie monastery męskie na terenie eparchii lwowskiej w latach 1596-1739. Przyczynek do powstania nowego katalogu». In Klasztory mnisze na wshodnich terenach 
dawnej Rzeczypospolitej od XVI do początku XX wieku, red. J. Gwiożdzik, R. Witkowski, A. Wyrwa, 277-286. Poznań, 2014.

Pawłyszyn, Andrij. Monastery męskie eparchii lwowskiej w latach 1596-1739. Praca doktorska. Lublin, 2006 (maszynopis).

Petrushevych, Antonii. Svodnaia Halitsko-Russkaia lietopis s 1600 po 1700 god. Lvov, 1874.

Pidłypczak-Majerowicz, Maria. «Polska literatura bibliologiczna na temat badań proweniencyjnych w zbiorach starych druków. Zarys problemu». In Kraków-Lwów: Biblioteki XIX-XX wieku. XIII: 7-21. Kraków, 2014.

Rodak, Paweł. Pismo, książk, lektura. Rozmowy: Le Goff, Chartier, Hébrard, Fabre, Lejeune. Warszawa, 2009.

Shchurat, Vasyl. «Khristos paskhon. Lvivski virshovani dialohy z 1630 r.» Zapysky Naukovoho tovarystva imeni Shevchenka 117-118 (1913): 137-178.

Shkrabiuk, Petro. Krekhiv: dorohy zemni i nebesni. Lviv, 2002.

Shustova, Yulia. Dokumienty Lvovskogo Uspienskogo Stavropigiiskogo bratstva (1586-1788): Istochnikoviedchieskoie issliedovaniie. Moskva, 2009.

Sinkevych, Natalia. «Sylvestr Kosov — vykladach KyievoMohylianskoho kolehiumu: rekonstruktsiia navchalnykh kursiv cherez pryzmu intelektualnykh interesiv vykladacha». In Shliakh u chotyry stolittia. Materialy Mizhnarodnoi naukovoi konferentsii «Ad fontes - Do dzherel» do 400-i richnytsi zasnuvannia Kyievo-Mohylianskoi akademii (12-14 zhovtnia 2015 roku), 41-50. Kyiv, 2016.

Sinkevych, Natalia. Paterykon Sylvestra Kosova: pereklad ta doslidzhennia pamiatky. Kyiv, 2014.

Sinkevych, Nataliia. Laudare benedicere praedicare: Dominikanskyi orden na Volyni v kintsi XVI - na pochatku XIX st. Kyiv, 2009.

Sitnikova, L. «Vilenskiie kirillovskiie izdaniia kontsa XVI — piervoi poloviny XVII v. vo lvovskikh sobraniiakh». In Fiedorovskiie chtieniia 1982. Moskva, 1987.

Skruten, Ivan Yosafat. "Synopsys" Plisnesko-Pidhoretskoho monastyria». Zapysky ChSVV vol. 1, issue 1 (Lviv, 1924): 92-103; vol. 1, issue 2 (Lviv, 1925): 303-313; vol. 1, issue 4 (Lviv, 1927): 580-591; vol. 3, issue 1 (Lviv, 1930): 156-164.

Tsentralnyi derzhavnyi istorychnyi arkhiv Ukrainy u m. Lviv, f. 129, op. 1, spr. 539, 1033, 1034.

Tsentralnyi derzhavnyi istorychnyi arkhiv Ukrainy u m. Lviv, f. 684, op. 1, spr. 2186, 3009. 
Velykyi Skyt u Karpatakh. Vol. 1: Pateryk Skytskyi. Synodyk, edited by M. V. Kuhutiak. Ivano-Frankivsk: Manuskrypt-Lviv, 2013.

Velykyi Skyt u Karpatakh. Vol. 2: Velykyi Skyt u dokumentakh i materialakh XVII-XXI st., edited by M. V. Kuhutiak. Ivano-Frankivsk: Manuskrypt-Lviv, 2015.

Vuitsyk, Volodymyr. «Monastyr Sviatoho Onufriia u Lvovi». In Vuitsyk V. Vybrani pratsi. Do 70-richchia vid dnia narodzhennia, 48-59. Lviv, 2004.

Vuitsyk, Volodymyr. «Oboronnyi vasylianskyi monastyr v Terebovli». Visnyk instytutu «Ukrzakhidproektrestavratsiia» 11 (2000): 39-48.

Vyrskyi Dmytro. Roksolany sered Sarmativ: richpospolytska istoriohrafiia Ukrainy (kinets XV st. - 1659). Kyiv, 2013.

Wyczawski, Hieronim. "Kościelne zbiory biblioteczne (wiek XVIXVIII)». In Dzieje teologii katolickiej w Polsce. T. 2: Od odrodzenia do oświecenia, cz. 1: Teologia humanistyczna, 519-551. Lublin, 1975,

Yakovenko, Natalia. U poshukakh Novoho neba: Zhyttia i teksty Yoanykiia Galiatovskoho. Kyiv: Laurus; Krytyka, 2017.

Yaremenko, Maksym. "Kyivski monastyrski ta pryvatni chernechi biblioteky XVIII stolittia i «literaturni upodobannia» monashestva». Ukrainskyi arkheohrafichnyi shchorichnyk 8/9 (2004): 346-365.

Zapasko, Yakym, and Isaievych, Yaroslav. Pamiatky knyzhkovoho mystetstva. Kataloh starodrukiv, vydanykh na Ukraini. Vol. 1 (1574-1700). Lviv, 1981.

Zhukovskyi, Arkadii. Petro Mohyla i pytannia yednosty tserkov. Kyiv, 1997.

\section{Abstract}

\section{Lectio Orthodoxorum: Libraries of the Orthodox Monasteries of the Lviv Eparchy in the Late $16^{\text {th }}-17^{\text {th }}$ Centuries}

The problem of the «readers' canon» representation in the Ukrainian Orthodox monasteries in the Early Modern period is studied by examining the libraries of the Krekhiv, St. Onuphrius in Lviv, Pidhirci and Terebovlya monasteries in the Lviv Eparchy. The book culture of the monasteries of the "Kyivan tradition" is considered in comparison with the book culture of the Catholic monasteries in the Polish-Lithuanian 
Commonwealth. In general, the mentioned libraries were small in comparison with the Catholic monastery libraries; for example, the largest one in Krekhiv consisted of approximately 100 volumes. Lectio Orthodoxorum is represented, besides liturgical books, by the thematic "triad" of patristic, hagiography, and preaching literature. And it does not look peculiarly, because similar literature was in Russian or Bulgarian Orthodox monastery libraries. For instance, Bulgarian monastery libraries mostly consisted of manuscript liturgical books, collections of sermons, etc. However, the same monasteries under consideration, such as Basilian in the $18^{\text {th }}$ Century, were completely different according to the thematic review. Additionally, Lectio Orthodoxorum was almost entirely composed of literature in Cyrillic. Only a few books were in Latin or in Polish. It means that the monasteries under study were not examples of so called «Polonica Orthodoxe», and the monks were not the part of contemporary Latin respublica litterarum. «Secular», and especially ancient literature, which was considered fundamental for a Westernoriented humanistic educational system, was lacking in the mentioned monasteries, and so were the books in Latin. This presents an indirect evidence about the degree and kind of education of those monks. It also suggests that, in general, the monks in these monasteries did not need a larger or more differentiated kind of literature. The liturgical cycle in the monasteries determined all their monastic life, and they were basically focused on prayer: intellectual activity, including reading of books, was probably beyond their scope and needs.

Keywords: monastery library, book culture, monasticism, book lists, Slavia Orthodoxa, Lviv Eparchy, Krekhiv monastery, St. Onuphrius Lviv monastery, Pidhirci monastery. 